\title{
Examining the Application of Deterrence in Sentencing in Malawi
}

\author{
E Gumboh*
}

\section{P.E.R}

Pioneer in peer-reviewed, open access online law publications

Author

Esther Gumboh

Affiliation

University of Cape Town

South Africa

Email nyagumboh2@gmail.com

Date published

18 December 2017

Editor Prof W Erlank

How to cite this article

Gumboh E "Examining the

Application of Deterrence in

Sentencing in Malawi" PER / PELJ 2017(20) - DOI

http://dx.doi.org/10.17159/1727-

3781/2017/v20i0a1167

\section{Copyright}

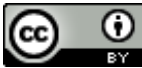

DOI

http://dx.doi.org/10.17159/17273781/2017/v20i0a1167

\begin{abstract}
This article is an exposition of the application of deterrence in Malawian sentencing jurisprudence. Drawing from case law, it explores how courts employed deterrence before 1994 and the role deterrence continues to play in the constitutional era. The paper looks at how it is reflected in the treatment of sentencing factors and influences sentencing policy. It also considers how courts have conceptualised the distinction between specific and general deterrence regarding the principle of proportionality and repeat offenders. The paper concludes with a discussion of an emerging attempt to go beyond deterrence towards giving rehabilitation a greater role in sentencing.
\end{abstract}

\section{Keywords}

Sentencing; deterrence; punishment; Malawi criminal law. 


\section{Introduction}

Sentencing is one of the most difficult aspects of a criminal trial, not least because of the competing interests that are at play. A crucial task that a court is faced with is determining the purpose to be served by a sentence; that is, whether the sentence should aim at deterrence, retribution, community protection or rehabilitation. The chosen purpose will inform the emphasis that the court places on sentencing factors. In a constitutional democracy like Malawi, a general question is how punishment should be applied in a way that is consistent with the 1994 Constitution. The Constitution expressly requires the state to

... promote law and order ... through the humane application and enforcement of laws and policing standards. ${ }^{1}$

Chirwa aptly notes that the Bill of Rights and human dignity in particular have "created a new blueprint for the administration of justice". ${ }^{2}$ The Constitution guarantees an array of rights to every person. Section 19 enshrines the right to human dignity. This right demands that fair punishment must be imposed and that it must be enforced in a humane manner. ${ }^{3}$ The Constitution specifically requires that human dignity must be respected in all judicial proceedings or any proceedings before any organ of state and during the enforcement of a penalty, ${ }^{4}$ and prohibits corporal punishment, torture, cruel, inhumane and degrading treatment or punishment. ${ }^{5}$ These provisions have significant implications for the aims and severity of criminal punishment and the manner in which it is enforced. The Constitution also recognises a range of rights that seek to protect the liberty of persons. ${ }^{6}$ The right to personal liberty is expressly protected in section 18.

Esther Gumboh. LLB Hons (UNIMA) LLM in Criminal Law (UCT) LLD (UCT). Postdoctoral fellow at the University of Cape Town, South Africa. Email: nyagumboh2@gmail.com.

1 Section 13(m) of the Constitution of the Republic of Malawi, 1994 (the Constitution). Although this principle is not justiciable, courts are enjoined to have regard to it not only when applying and interpreting the Constitution and legislation but also when reviewing decisions by the executive: see Masangano $v$ Attorney General Constitutional Case No 15 of 2007 (HC) 34-35 and 44-45.

Chirwa Human Rights under the Malawian Constitution 126.

Chirwa Human Rights under the Malawian Constitution 127.

Section 19(2) of the Constitution.

Section 19(3) of the Constitution.

This includes the right to dignity (s 19), the prohibition of corporal punishment, torture, cruel, inhumane and degrading treatment or punishment, the right to personal liberty ( $s$ 18) and other fair trial rights in $s 42$, such as the right to be promptly informed of the reason for one's detention, to be brought before a court of law within 48 hours, to be released from detention with or without bail, to be detained 
This article examines the application of deterrence in Malawian sentencing jurisprudence. Drawing from case law, it explores how courts employed deterrence before 1994 and the role it continues to play in the constitutional era. The paper looks at how deterrence is reflected in the treatment of sentencing factors and influences sentencing policy. It also considers how courts have conceptualised the distinction between specific and general deterrence with regard to the principle of proportionality and repeat offenders. The paper concludes with a discussion of an emerging trend to go beyond deterrence in order to give rehabilitation a greater role in sentencing.

\section{The theory of deterrence}

\subsection{Definition and overview}

Deterrence is a utilitarian theory of punishment. Utilitarianism is a moral theory that states that the ultimate good of society is to achieve happiness or pleasure and to avoid pain. ${ }^{7}$ It is governed mainly by the principle of utility, which judges conduct by its ability to increase happiness or reduce pain. ${ }^{8}$ An action is morally reasonable and defensible if it produces "the greatest happiness to the greatest number" of people. ${ }^{9}$ As a utilitarian theory, deterrence justifies punishment by its ability to prevent future crime in society. ${ }^{10}$ The punishment of an offender, though unpleasant and bringing unhappiness to him, is justified by its overall benefit of increasing societal happiness through crime prevention. ${ }^{11}$ The theorisation of deterrence is mainly attributed to the early works of philosophers such as Thomas Hobbes, Cesare Beccaria and Jeremy Bentham. Deterrence occurs when a person refrains from an action because of the fear of the possible unpleasant consequences of that action. It assumes that offenders or potential offenders will not commit further offences for fear of being punished. To achieve this, the punishment must be sufficient to outweigh

in humane conditions, to challenge the lawfulness of one's detention and to be released immediately if such detention is unlawful. The Constitution also gives children additional rights such as the right to be treated in a manner that promotes their "reintegration into society to assume a constructive role", to not be sentenced to life imprisonment without the possibility of release and to be imprisoned only as "a last resort and for the shortest period of time consistent with justice and public protection". The Constitution also embraces international law as a source of law and an interpretative aid (s 11(2)(c)), bringing into play international standards of punishment.

See generally Bykvist Utilitarianism 16-30.

Bentham Principles of Morals and Legislation 11-12.

Bentham "Comment on the Commentaries" 393.

Marsh, Cochrane and Melville Criminal Justice 8.

Hospers Human Conduct 454. 
the profit of the offence. ${ }^{12}$ Deterrence depends on the frightening effect of punishment emanating from the risk of discovery and punishment outweighing the temptation to commit an offence. ${ }^{13}$ Deterrence can be specific or general. Specific deterrence aims to discourage the punished offender from re-offending by instilling fear in the offender of being punished again while general deterrence aims at preventing potential offenders from committing crimes. ${ }^{14}$

The severity and certainty of punishment are key concepts in deterrence. ${ }^{15}$ Both Beccaria ${ }^{16}$ and Bentham ${ }^{17}$ believe that punishment must exceed the benefits derived from the crime committed. They explain that severity applies to both the quantum and nature of punishment and that unjust punishments are those which exceed the quantum that was necessary to achieve deterrence. ${ }^{18}$ Beccaria adds that the quantum of punishment must rise with the profit of the offence. ${ }^{19} \mathrm{He}$ regards the certainty of arrest and punishment as more fundamental to the preventive force of punishment than severity. ${ }^{20}$ Severe punishment must be coupled with the certainty not only of being caught but also being convicted; otherwise, the punishment remains a threat only on paper. In addition, punishment must be swift. Beccaria explains that

[t]he more immediately after the commission of a crime a punishment is inflicted, the more just and useful it will be. ${ }^{21}$

He further clarifies that the immediacy of punishment is crucial in that it ensures that punishment is seen as the inevitable consequence of crime. ${ }^{22}$ This implies that the swiftness of punishment will add to its deterrent effect. ${ }^{23}$ Thus, Beccaria regards the prerogative of mercy and other forms of early

\footnotetext{
12 Bentham Principles of Morals and Legislation 166.

13 Andenaes Punishment and Deterrence 7.

$14 \quad$ Cavadino and Dignan Penal System 34.

15 Apel and Nagin "General Deterrence" 412.

16 Beccaria 1764 http://files.libertyfund.org/files/2193/Beccaria_1476_EBk_v6.0.pdf 49.

17 Bentham Principles of Morals and Legislation 166.

18 Bentham Principles of Morals and Legislation 166; Beccaria 1764 http://files.libertyfund.org/files/2193/Beccaria_1476_EBk_v6.0.pdf 49.

19 Beccaria 1764 http://files.libertyfund.org/files/2193/Beccaria_1476_EBk_v6.0.pdf 49.

Maestro Cesare Beccaria 29.

Beccaria 1764 http://files.libertyfund.org/files/2193/Beccaria_1476_EBk_v6.0.pdf 39.

22 Beccaria 1764 http://files.libertyfund.org/files/2193/Beccaria_1476_EBk_v6.0.pdf 39. 
release or reduction of sentences based on mitigating factors as detrimental to the certainty of punishment:

To show mankind that crimes are sometimes pardoned, and that punishment
is not the necessary consequence, is to nourish the flattering hope of impunity,
and is the cause of their considering every punishment inflicted as an act of
injustice and oppression. The prince in pardoning gives up the public security
in favour of an individual, and, by his ill-judged benevolence, proclaims a
public act of impunity. ${ }^{24}$

The underlying assumption of deterrence is that human beings are rational actors who will weigh the profit of crime against its cost, including the applicable punishment. Proponents of deterrence therefore accept that deterrence is an inappropriate consideration for the mentally ill, the young, or those who committed the offence while provoked. ${ }^{25}$ On the other hand, severe, swift, certain punishment will act as a deterrent for rational beings. This means that in addition to severity and certainty, the citizenry must be adequately informed about the applicable punishment and the actual sentences that are imposed on offenders. ${ }^{26}$ This is particularly important for general deterrence. ${ }^{27}$ Bentham states that punishment is inefficacious where the "the penal provision, though established, is not conveyed to the notice of the person on whom it seems intended that it should operate". ${ }^{28}$ The public must also have sufficient details about the crime. ${ }^{29}$

\subsection{Critical appraisal of deterrence}

Deterrence can be credited for not ignoring the consequences of punishment in that it seeks to apply it for the betterment of society. Consequently, it may be relevant in assessing harsh punishment that satisfies retribution but has no benefit to society. This would be vital in assessing the acceptability of some forms of punishment. However, deterrence has its own problems which disqualify it from being a dominant penal theory.

The first criticism of deterrence is that it runs the danger of justifying excessive punishment based on its perceived positive consequences. Consequently, it dehumanises an offender, failing to recognise man as an end in himself. This is contrary to the principle put forward by Kant that

24 Beccaria 1764 http://files.libertyfund.org/files/2193/Beccaria_1476_EBk_v6.0.pdf 80.

$25 \quad$ Fox and Freiberg Sentencing 211.

$26 \quad$ Christopher 2002 NWULR 856.

$27 \quad$ Zimring Perspectives on Deterrence 76.

28 Bentham Principles of Morals and Legislation 160.

29 Geerken and Gove 1975 Law \& Soc'y Rev 507. 
human beings are ends in themselves and should not be treated as means to an end. ${ }^{30}$ In $S$ v Makwanyane, the South African Constitutional Court held that deterrence "instrumentalises the offender for state policy",

dehumanises ... and objectifies him ... as a tool for crime control. This objectification ... strips the offender of his ... human dignity. ${ }^{31}$

However, this criticism is valid only where, for the purposes of deterrence, the punishment imposed on an offender is increased beyond that which is otherwise proportional to the offence committed.

Another weakness with deterrence is that it is often used to justify stiffer sentences. Any penal policy that increases the length or nature of the punishment applicable is generally based on deterrence. ${ }^{32}$ The problem is that deterrence fails to provide a measure for the quantum of punishment. If penalties must be "sufficiently" severe, then the prevalence of an offence will mean that a punishment has not achieved general or specific deterrence, which in turn will be taken to mean that the punishment is too lenient. Therefore, harsher sentences may be imposed if the desired effect is not achieved. ${ }^{33}$ In some cases, the law may even resort to mandatory and minimum sentences. These sentences run the risk of disproportionality because they restrict or rule out a court's sentencing discretion and therefore ignore the circumstances of an offender. Proportionality requires that a sentence must be tailored to fit the circumstances of the crime and the offender. This cannot be properly achieved if a court does not have the discretion to individualise a sentence.

Deterrence focuses mainly on whether the punishment is sufficiently severe to act as a deterrent; thereby trivialising the circumstances of the offence and the offender. Therefore, a penal system based solely on deterrence is likely to achieve only skewed justice. Ignoring the individual means that deterrence is not prepared to accept the reformation of an offender as another aim of punishment or the importance of early release mechanisms. This undermines the individual even further and may violate the right to dignity and the prohibition of cruel, inhumane and degrading punishment. ${ }^{34}$

Kant "Penal Law and the Law of Pardon" 31-32.

S v Makwanyane 19953 SA 391 (CC) paras 313 and 316.

Apel and Nagin "General Deterrence" 412.

Wasik Emmins on Sentencing 46.

The absence of an early release mechanism may render life and long-term imprisonment unconstitutional. See, for instance, Vinter $v$ United Kingdom Application Nos 66069/09, 3896/10 and 130/10, Merits, 9 July 2013 (ECtHR); Kafkaris v Cyprus [2008] ECtHR. International standards for punishment dictate that all prisoners must be offered the possibility of rehabilitation and the prospect of release. See, for instance, art 10(3) of the International Covenant on Civil and 
Lastly, there are questions about whether deterrence works in practice and whether stiffer punishments help to reduce crime. There is no doubt that penalties do have a general deterrent effect. ${ }^{35}$ Indeed, few would argue that people would refrain from committing crimes if criminal activity attracted a reward. However, the relationship between the severity of punishment and its deterrent effect is a complicated one. Proponents of deterrence like Andenaes state that this complication arises because the fear of punishment is not the only factor that serves as a disincentive to committing crimes; the state of mind of the public and the intensity of policing are also important. $^{36}$ More importantly, some people are deterred by moral considerations or fear of disapproval from those close to them, regardless of the severity of the punishment or knowledge of it. ${ }^{37}$ Admittedly, the nature and severity of punishment is the easiest factor to regulate.

In summary, deterrence aims to prevent crime through the threat of punishment. This would necessitate that factors like the prevalence of the crime should be considered when sentencing an offender. Although there is no conclusive evidence as to how far deterrence works, it can play a limited role in punishment. People may learn from punishment, and it may thus provide a disincentive to crime. However, as noted above, a purely deterrence-based policy can result in harsh sentences. Proportionality considerations must therefore play a role in deciding the severity of punishment. Further, considering the inconclusive evidence regarding the relation between the severity of punishment and its deterrent effect, the legislature and the courts should be wary of increasing punishment as though deterrence were "an article of faith". ${ }^{38}$ The personal circumstances of the offender should also be considered.

Lastly, by requiring that the law and punishment must be communicated to the public, deterrence reinforces the principle of legality, which requires that criminal laws must be clear so that ordinary people know the proscribed conduct and its punishment. This will make punishment a proactive, as opposed to a reactive, measure against crime.

Political Rights (1966) which provides that the penitentiary system shall have as its essential aim the reformation and social rehabilitation of prisoners. Various UN and regional instruments and the jurisprudence of international human rights bodies echo the need for a prospect of release: see Gumboh $2017 \mathrm{JAL}$.

35 Van Den Haag 1982 J Crim L \& Criminology 1034.

$36 \quad$ Andenaes Punishment and Deterrence 22.

$37 \quad$ Cavadino and Dignan Penal System 36.

$38 \quad$ Fox and Freiberg Sentencing 210. 


\section{Deterrence in Malawian sentencing jurisprudence}

\subsection{Deterrence before 1994}

Before the Constitution was adopted in 1994, the aims of punishment were largely deduced from the aims of criminal law. It was recognised that the aim of criminal law was not just retribution but ultimately crime prevention. Therefore, the courts emphasised crime prevention as the primary purpose of punishment. This required that deterrence and community protection (incapacitation) should be the priority in sentencing. In $R v$ Robert, ${ }^{39}$ Villiera $J$ held:

The first and foremost [consideration in sentencing] is the public interest. The
criminal law is publicly enforced, not only with the object of punishing crime,
but also in the hope of preventing it. A proper sentence passed in public serves
the public interest in two ways. It may deter others who might be tempted to
try crime as seeming to offer easy money on the supposition that if the
offender is caught and brought to justice the punishment will be negligible.
Such a sentence may also deter the particular offender from committing a
crime again or induce him to turn from criminal to honest living.

Accordingly, deterrence and community protection were individually seen as major aims of punishment. ${ }^{40}$ Community protection was often regarded as a justification for imposing long and immediate sentences for serious offences. In Banda and Others $v$ Rep ${ }^{41}$ the Malawi Supreme Court of Appeal (MSCA) held that serious offences should be severely punished with long prison sentences to protect the public, and that the goal of public protection would in such cases justify an order that the sentences should run consecutively. Similarly, in Rep $v$ Phale ${ }^{42}$ the court held that community protection was a justification for imposing otherwise harsh sentences in serious cases. Apart from community protection, long and immediate sentences were also considered necessary in serious cases to mark the gravity and public disapproval of the offence, and to punish the offender. ${ }^{43}$ The pursuit of community protection and deterrence, especially where the offence was serious, would also justify a departure from sentencing principles provided this did not result in an extraordinarily excessive sentence. ${ }^{44}$

$R v$ Robert [1961-1963] 2 ALR Mal 291 (HC) 293.

Rep v Mpira [1982-1984] 10 ALR Mal 67 (HC).

Banda v Rep [1990] 13 MLR 56 (SCA) 59.

Rep v Phale [1991] 14 MLR 438 (HC).

Rep v Msowoya [1987-1989] 12 ALR Mal 394 (HC).

Kamil v Rep [1973-1974] 7 MLR 169 (SCA); Kumwenda v Rep (1993) 16(1) MLR 233 (SCA). 
In employing deterrence the courts distinguished between specific and general deterrence. Specific deterrence provided the rationale for considering an offender's criminal record in sentencing; unlike first offenders, repeat offenders were not entitled to leniency. ${ }^{45}$ The reason for this was that a repeat offender showed that he had not learnt from or been deterred by his previous punishment. This rationale was evident, for example, in the general principle that the significance of previous convictions diminished with time. ${ }^{46}$ The justification for this principle was that a lapse of time between the previous conviction and the current one must be considered in the offender's favour as an indication that the defendant has demonstrated that he tried to lead a clean life. ${ }^{47}$ In 1964, however, Cram $\mathrm{J}$ held that a reasonable and proper sentence is one that is appropriate to the offence and the circumstances and that is not enhanced merely because the convict has previous convictions: ${ }^{48}$

[l]t is not right to hold over a man's past offences which have been dealt with by appropriate sentences, as we must assume [that] past offences have been dealt with, and add them up and increase ... the severity of sentence for a later offence. That is dangerously like punishing a man twice for an offence. If a man who has been convicted shows himself unresponsive to leniency and persists in life of crime, that is a reason for giving him the proper and deserved sentence in the particular case. If, on the other hand, there are some merits, it may be that the court will treat him more leniently because he has shown himself in some way responsive to the warning which he has had.

General deterrence, aimed at deterring potential offenders, entailed that the prevalence of an offence was a basis for increasing a sentence. ${ }^{49}$ This meant that like community protection, general deterrence was often used to justify stiff sentences in the form of long and immediate imprisonment in punishing serious cases. ${ }^{50}$ In addition, it justified departure from established sentencing principles. ${ }^{51}$ Suspended sentences were generally seen as inadequate for general deterrence. In Rep $v$ Nabanda, ${ }^{52}$ for example,

$45 \quad R v$ White [1923-1960] 1 ALR Mal 401 (HC); Bwanali $v R$ [1964-1966] 3 ALR Mal 329 (HC). Compare Makawa v Rep Criminal Appeal No 196 of 1975 (HC) where previous convictions were used to justify the imposition of the maximum penalty; Maikolo v R [1964-1966] 3 ALR Mal 584 (SCA); Rep v Havula [1991] 14 MLR 429 (HC); Chief Public Prosecutor v Nkosi [1990] 13 MLR 97 (HC) (previous convictions are evidence of bad character). Rendall-Day v Rep [1966-1968] 4 ALR Mal 155 (HC). John $v$ Rep Criminal Appeal No 131 of $1975(\mathrm{HC})$, where a lapse of six years prompted the court to disregard the offender's criminal record. Maikolo v R [1964-1966] 3 ALR Mal 584 (SCA) 594. Rep v Phiri [1993] 16(2) MLR 748 (HC); $R$ v Zagwa [1923-1960] 1 ALR Mal 415 $(\mathrm{HC})$.

Rep v Katole [1993] 16(1) MLR 472 (HC); Mpondamwala v Rep [1984-1986] 11 ALR Mal 306 (HC). Kamil v Rep [1973-1974] 7 MLR 169 (SCA). [1984-1986] 11 ALR Mal 166 (HC). 
Unyolo $\mathrm{J}$ held that a serious offence like child stealing should be punished with immediate imprisonment because a suspended sentence would send a wrong signal to the offender and potential offenders.

Interestingly, courts were of the view that general deterrence was not a suitable goal of punishment for first and young offenders. Hence, courts often refrained from imposing lengthy sentences on these offenders. Relying on Rep $v$ Banda, ${ }^{53}$ the court held in Rep $v$ Domingo ${ }^{54}$ that it is in the public interest that young offenders must not be used as ends for general deterrence. It added that where young offenders were concerned, general deterrence might still be achieved through short sentences. ${ }^{55}$ The rationale for this was that general deterrence entailed long sentences which were deemed unsuitable for such offenders as they would inhibit their rehabilitation. This reasoning clearly underscores the fact that general deterrence was synonymous with long sentences.

It is important to mention that courts generally viewed first offenders as more likely to respond positively to punishment or the threat of punishment. For instance, Jere $\mathrm{J}$ remarked in Rep $v$ Matindi: 56

The philosophy behind [suspended sentences] is that first offenders should be kept out of prison because contact with hardened criminals might have a bad influence on them, and, secondly, they should be given a chance to mend their ways but with a real threat that if they commit another offence during the period, the suspended sentence will be revived. In this way, therefore, the suspended sentence provides an incentive to first offenders to keep the law.

This reasoning presupposes that first offenders have a greater chance of changing their ways than repeat offenders. Thus, specific deterrence was likely to be achieved when dealing with first offenders. In fact, according to Chatsika J,

[i]t has been proved in certain cases that certain persons who are tempted to commit offences thinking that they would not be found, refrain from falling into similar temptations, when they have once been found and subjected to terms of imprisonment which have been suspended. ${ }^{57}$

The soundness of this position is considered in section 4.3.1 below.

\footnotetext{
53 Rep v Banda [1984-1986] 11 ALR Mal 166 (HC), 7.

$54 \quad$ Rep v Domingo Confirmation Case No 850 of $1990(\mathrm{HC})$.

55 See also Rep v Nthara [1984-1986] 11 ALR Mal 338 (HC); Maniote v Rep [19841986] 11 ALR Mal 174 (HC); Rep v Phiri [1984-1986] 11 ALR Mal 176 (HC).

56 Rep v Matindi Confirmation Case No 1699 of 1976 (HC).

$57 \quad$ Kalambo v Rep Criminal Appeal No 199 of 1975 (HC).
} 


\subsection{Deterrence after 1994}

The judicial position on the role of deterrence has not changed much since 1994. In Rep v Alick, deterrence was described as "the primary purpose of punishment and the criminal process". ${ }^{58}$ Similarly, Rep $v$ Kufandiko ${ }^{59}$ held that the first and foremost issues among public interest considerations during sentencing are deterrence and antecedents. Also, it is generally believed that deterrence calls for stiffer sentences. ${ }^{60}$ However, unlike before 1994, it is now stressed and readily accepted that the purposes of sentencing are not to be confused with sentencing principles. ${ }^{61}$ Therefore, it is not acceptable to invoke deterrence as a justification for imposing sentences that are otherwise disproportional to the offence and the offender.

Deterrence is usually employed for prevalent, serious and violent offences such as robbery, burglary, ${ }^{62}$ housebreaking, ${ }^{63}$ rape and theft by a servant. ${ }^{64}$ General deterrence is also invoked in punishing offences involving the obstruction of public duty and the administration of justice such as resisting lawful arrest ${ }^{65}$ and escaping from lawful custody. ${ }^{66}$ In such cases immediate imprisonment is likely to be imposed, to send out a warning to potential offenders. Further, in order to maximise the deterrent effect, it has been held that sentences for serious offences should run consecutively to a sentence that is being served. ${ }^{67}$ The courts have stressed that as a general principle serious and prevalent offences must be punished with long and immediate imprisonment. ${ }^{68}$ This is departed from only in "extremely rare" or exceptional circumstances when the mitigating factors outweigh the aggravating factors

\footnotetext{
$58 \quad$ Rep $v$ Alick Confirmation Case No 725 of 2000 (HC).

59 Rep v Kufandiko Confirmation Case No 126 of 2009 (HC).

$60 \quad$ Rep v Madelube Criminal Case No 105 of 2008 (HC) 4.

$61 \quad$ Rep v Kayenda Confirmation Case No 220 of 2003 (HC).

62 Rep v Misomali Confirmation Case No 527 of 1996 (HC).

$63 \quad R e p$ v Tomasi [1997] 2 MLR 70 (HC); Rep v Tembo Confirmation Case No 726 of $2000(\mathrm{HC})$ (irrespective of the mitigating factors, a simple burglary should be punished with no less than three years). Rep v Madando [1995] 2 MLR 733 (HC); Banda v Rep Criminal Appeal No 221 of 2009 (HC).

$65 \quad$ Rep v Harry [1997] 1 MLR 119 (HC); Rep v Matiki [1997] 1 MLR 159 (HC). Rep v Lampu Confirmation Case No 89 of 1996 (HC); Rep v Gwaza [1995] 2 MLR 752 (HC) 754 ("The news of escape from prison may spread to inmates like bushfire and they may attempt to try their luck too"). Rep v Gwaza [1995] 2 MLR 752 (HC) 754. See also Rep v Matiki [1997] 1 MLR 159 (HC) 162, holding that a sentence for resisting lawful arrest must run consecutively to a sentence for the substantive offence. No 93 of 2005 (HC) 5; Rep v Austin Confirmation Case No 1222 of 2003 (HC); Rep v Mzuzi Confirmation Case No 1607 of 1998 (HC).
} 
"considerably", such that a court may opt to suspend the sentence or impose a non-custodial one. ${ }^{69}$

However, the fact that an offence is serious does not imply that imprisonment must be imposed automatically. The Magistrate's court sentencing guidelines state that reasons must be given as to why an offence is so serious as to justify imprisonment. ${ }^{70}$ In practice, however, serious offences are still likely to attract long and immediate imprisonment, even in the presence of strong mitigating factors: ${ }^{71}$

[S]ome crimes are so heinous that a plea of youth, a plea that the crime was a first offence or that the offender has never been in prison before is irrelevant. Those who participate in such crimes should know that they will be subjected to long and immediate imprisonment, though they are young, even if they pleaded guilty, even if they had no previous convictions, even if the victims were neither young nor infirm. Courts will not readily accede to pleas of guilty or the age of the defendant where offences are very serious and committed in the most austere of circumstances. ${ }^{72}$

Courts have gone even further to prescribe starting points for various offences and flagged them for long and immediate imprisonment. These include rape (six years), ${ }^{73}$ robbery (three ${ }^{74}$ or four ${ }^{75}$ years), burglary and housebreaking (six years), ${ }^{76}$ arson (three years) ${ }^{77}$ and theft of cattle (12 months). ${ }^{78}$ The Sentencing guidelines adopt this approach and prescribe starting points for about 43 offences. ${ }^{79}$ Shorter sentences are considered more appropriate for what are deemed to be less serious offences such as breaking into a building, minor cases of sexual indecency, petty frauds, assaults and other instances of violence causing minor injuries. ${ }^{80}$

\footnotetext{
$69 \quad$ Rep v Tomasi [1997] 2 MLR 70 (HC) 72.

70 Malawi Judiciary Magistrate's Court Sentencing Guidelines.

$71 \quad$ Mussa $v$ Rep Criminal Appeal No 44 of 1995 (HC).

72 Also see Rep v Mkoma [1995] 2 MLR 598 (HC) 601; Rep v Mtaya Confirmation Case No 98 of 1995 (HC); Mbekeani v Rep Criminal Appeal No 48 of 2006 (HC) 20; Lusale $v$ Rep Criminal Case No 141 of 2005 (HC); Lobo v Rep Criminal Appeal No 110 of 2008 (HC). Rep v Ndamera Confirmation Case No 314 of 2001 (HC). Compare Rep v Msowoya [1987-1989] 12 ALR Mal 394 (HC) 394, recommending three years as the starting point for rape if the aggravating factors equal the mitigating factors. Rep v Harry [1997] 2 MLR 74 (HC).

Rep v Napulula Confirmation Case No 665 of 2003 (HC).

Rep v Chizumila [1994] MLR 288 (HC) (hereafter Chizumila).

77 Rep v Kathumba [1997] 1 MLR 390 (HC) 392; Rep v Chitseko Confirmation Case No 78 of 1997 (HC). See also see Malawi Judiciary Magistrate's Court Sentencing Guidelines 40. Rep v Phiri [1997] 2 MLR 92 (HC) 94. If the matter involves goats, the starting point is six months: see Malawi Judiciary Magistrate's Court Sentencing Guidelines 30. See Malawi Judiciary Magistrate's Court Sentencing Guidelines 9-51. Rep v Iddi Confirmation Case No 48 of 1998 (HC).
} 
The general principle that serious offences must be punished with immediate imprisonment is also underscored by considerations of community protection which may require that an offender should be removed from society. However, the principle is also accentuated by the perception that non-custodial sentences and short prison terms are generally insufficient for deterrence. ${ }^{81}$

\subsection{Deterrence and other sentencing factors}

Deterrence is also reflected in the emphasis placed on some sentencing factors such as previous convictions and domestic obligations. While most cases continue to consider previous convictions in sentencing, ${ }^{82}$ some courts have criticised this practice. For example, Rep $v$ Sozinyo ${ }^{83}$ held that, except where statute provides for an enhanced sentence for a second offence, ${ }^{84}$ enhancing a sentence based on previous convictions is

... tantamount to punishing an offender twice over for offences for which he has already been punished. 85

It can be argued that if enhancing a sentence based on previous convictions breaches the principle of double jeopardy and therefore the right to a fair trial, it is fictitious to regard legislation-sanctioned enhancements any differently.

81 Rep v Tomasi [1997] 2 MLR 70 (HC). In Rep v Josephy Confirmation Case No 261 of 2013 (HC), a short immediate sentence of six months was justified on the basis that it was imposed for deterrent purposes and that community service is not generally seen as fit for this purpose.

82 See for instance Rep v Phiri [1996] MLR 365 (HC); Moses v Rep Confirmation Case No 140 of 2011 (HC); Rep v Kafwambira Confirmation Case No 37 of 2008 (HC); Rep $v$ Jumbe Criminal Appeal No 565 of 2008 (HC); Dandaula v Rep Criminal Appeal No 11 of $2008(\mathrm{HC})$. The failure to respond to past sentences may affect the seriousness of an offence: see Malawi Judiciary Magistrate's Court Sentencing Guidelines 53.

83 Rep v Sozinyo [1997] 2 MLR 16 (HC).

84 Malawian statutory law is awash with provisions that prescribe higher sentences for a second offence: see ss 88(3) (official corruption), 169(4) (offences relating to gaming houses), 180 (idle and disorderly persons), 184 (rogues and vagabonds) and 183(1) (nuisances by drunken persons) and 290 (theft) of the Penal Code, Chapter 7:01 of the Laws of Malawi; ss 29, 90(11), 126(4)(c), 128(9)(b), 141(3), 152(4)(b), 153(2)(b) of the Road Traffic Act, Chapter 69:01 of the Laws of Malawi.

$85 \quad \operatorname{Rep} v$ Sozinyo [1997] 2 MLR 16 (HC) 18. See also Rep v Chizenga Confirmation Case No 297 of 2008 (HC); Rep v Ngomwa Confirmation Case No 1021 of 2003 (HC) 2 (previous offences "must be deemed to have been paid for by the penalties that attached to them and so they do not attract extra punishment, so to speak"); Rep $v$ Kapitawo Confirmation Case No 303 of 2005 (HC) (it is wrong to base sentence on the fact that the accused is not a first offender). 
The treatment of pleas of family hardship or obligations also highlights the significance of deterrence in punishment. ${ }^{86}$ These pleas usually arise in connection with immediate imprisonment as it involves the removal of an offender from his family and exposes him to the risk of losing a job. The general rule is that domestic obligations are not relevant to sentencing, let alone the decision to imprison. ${ }^{87}$ Departure from this general rule will be justified only if imprisonment will cause "unusual or exceptional hardship" to the offender's family, if the domestic obligations are "exceptional or unusual", or there are unusual or exceptional circumstances. ${ }^{88}$ Courts have often said that the possibility of imprisonment and resulting family hardship should have acted as a deterrent to committing crime in the first place. Chipeta J has stated that

[a] man who opts for and goes ahead to commit a crime should factor in the possibility that if the long arm of the law catches up with him and accords him a custodial penalty, his family will suffer and that the courts are not encouraged to be moved by such pleas. ${ }^{89}$

\section{Similarly, Millo $v$ Rep held that}

... offenders should put domestic matters in the equation when embarking in conduct society disapproves and enforces with criminal sanctions. ${ }^{90}$

86 The rejection of family obligations is also partly based on retribution and community protection: see Rep v Eneya Criminal Case No 53 of 2003 (HC) (considering family obligations may detract a court from imposing the right sentence by making it focus on the hardship a sentence may inflict on an offender's family); Chitsonga $v$ Rep [1995] 1 MLR 86 (HC) 88 (family hardship due to imprisonment is part of the price to pay when committing a crime).

87 Kanyinji v Rep Criminal Appeal No 116 of 2008 (HC); Rep v Mutawo Confirmation Case No 237 of 1999 (HC) (the obvious reason for rejecting domestic matters in sentencing is that offenders know that "they are likely to be sent to prison and that this will affect their children"); Millo v Rep Criminal Appeal No 30 of 2000 (HC) (public interest in criminal justice cannot be "easily dispelled by domestic considerations" and it "would be precariously compromised if courts unduly consider such matters"); Rep v Chimbelenga (1996) MLR 342 (HC) 354 (family responsibilities not considered in sentencing offender to 30 years for stealing over K1 million from the government). Rep v Mafaiti Confirmation Case No 660 of 1990 (HC); Rep v Mutawo Confirmation Case No 237 of 1999 (HC); Rep v Asidi Confirmation Case No 955 of 1999 (HC); Rep v Chilenje [1996] MLR 361 (HC) - test for exceptional circumstances is satisfied where the effect of imprisonment is to deprive young children of parental care or where a close family member is terminally ill. In other cases, courts have readily regarded ordinary family responsibilities as mitigating without applying the exceptional hardship test or having regard to the seriousness of the offence: see Makanjira v Rep Criminal Appeal No 67 of 2007 (HC) (offender responsible for grandparents and orphans); Rep v Kachimanga Confirmation Case No 1746 of 2007 $(\mathrm{HC})$ (caring for old grandmother accepted as mitigating factor); Daukire $v$ Rep Criminal Appeal No 148 of 2004 (HC); Rep v Chinthiti (2) [1997] 1 MLR 70 (HC). Rep v Eneya Criminal Case No 53 of 2003 (HC) 3. Also see Kapolo v Rep Criminal Appeal No 82 of 2007 (HC). Millo v Rep Criminal Appeal No 30 of 2000 (HC). 
The underlying assumption here is that offenders weigh their options carefully before committing an offence.

\subsection{Specific versus general deterrence}

Courts continue to distinguish between specific and general deterrence. ${ }^{91}$ In Rep v Wilson; Rep v Khapuleni and Others, ${ }^{92}$ Banda CJ was of the view that a first custodial sentence should be aimed at specific and not general deterrence. It was held in White $v$ Rep ${ }^{93}$ that a sentence should not be suspended if the aim is to achieve general deterrence such as where the offence is serious and public safety has been compromised such that meaningful and punitive sentences are deserved. ${ }^{94}$

According to Rep $v$ Nkhoma, ${ }^{95}$ general deterrence should attract lengthier sentences with an added "premium" of imprisonment for deterrent purposes. ${ }^{96}$ This literally means that sentences imposed for general deterrence are in effect disproportionate sentences. In fact, Rep v Chikwana unequivocally states that general deterrence entails

... passing a sentence that is beyond one the offender deserves based on the crime committed. ${ }^{97}$

Chikopa J observed in Rep $v$ Nkhata that punishment should not be used as a warning to the general public because this is punishing an offender for wrongs he has not committed. ${ }^{98}$ It was said in Rep $v$ Sakhwinya that general deterrence

... is immoral because it leaves the feeling that human beings can be used as a means to an end and ... it may be a cruel and degrading punishment under section 19(3) of the Constitution. ${ }^{99}$

$91 \quad$ Rep $v$ Nkhoma Confirmation Case No 3 of $1996(\mathrm{HC})$ (special deterrence is directed at preventing an offender from committing further crime); Rep $v$ Kufandiko Confirmation Case No 126 of 2009 (HC) 3 (a general deterrent sentence is an exemplary sentence imposed to prevent others from committing crimes).

92 Rep v Wilson; Rep v Khapuleni [1995] 2 MLR 567 (HC) 569, citing R v Curran 57 Cr App R 945.

$93 \quad$ White $v$ Rep Criminal Appeal No 19 of 2007 (HC).

94 Compare Rep v Nkhoma Confirmation Case No 3 of 1996: "The question of suspension of a sentence, a principle of sentencing, should be treated distinctively from the question of deterrence ... The question of suspension arises after, not before, an appropriate prison sentence has been arrived".

95 Confirmation Case No 3 of $1996(\mathrm{HC})$.

96 Also see Rep v Adam Confirmation Case No 500 of 1995 (HC).

$97 \quad$ Rep v Chikwana Confirmation Case No 131 of 2013 (HC) 4.

$98 \quad$ Rep $v$ Nkhata Confirmation Case No 534 of 2003 (HC).

$99 \quad$ Rep $v$ Sakhwinya Confirmation Case No 359 of 2013 (HC) 3. 
Similarly, it was observed in Rep $v$ Jeke that a sentence based on general deterrence

... is wrong in principle because it is tantamount to using (or is it abusing) humans as means to an end. Such sentences would be degrading cruel and inhuman(e) punishment or treatment. ${ }^{100}$

These sentiments have been reiterated in several High Court judgments such as Rep $v$ Kanena, ${ }^{101}$ Rep $v$ Foster, ${ }^{102}$ Rep $v$ Naphazi, ${ }^{103}$ Rep $v$ Tembo, ${ }^{104}$ Rep $v$ Kaufa, ${ }^{105}$ Rep $v$ Mulolo ${ }^{106}$ and Rep $v K_{\text {Kanyumba }}{ }^{107}$ to mention a few. However, except for the views expressed in Rep v Nkhata, ${ }^{108}$ all these sentiments have been expressed only to show that general deterrence is an inappropriate goal for the punishment of first offenders. In other words, the criticisms are justification for not imposing general deterrent sentences on first and young offenders, except where the offence is very serious. The general view is that sentences imposed on first offenders "can only be as [to] fit the offence and only for the purpose of reforming or preventing the offender from committing offences in the future". ${ }^{109}$

\subsection{Limiting the instrumentalisation argument: The special treatment of first and young offenders}

For first and young offenders, general deterrence is readily accepted by the courts as an automatic consequence of punishment. For instance, entrenching the position before 1994, it is often stated that punishment

\footnotetext{
100 Rep v Jeke Confirmation Case No 178B of $2013(\mathrm{HC})$ 4-5.

101 Rep v Kanena Confirmation Case No 130 of 2013 (HC).

102 Rep v Foster Confirmation Case No 1690 of 2005 (HC) 9.

103 Rep v Naphazi Confirmation Case No 386 of 2011 (HC) 4.

$104 R e p v$ Tembo Confirmation Case No 187 of 2013 (HC).

105 Rep v Kaufa Confirmation Case No 314 of $2011(\mathrm{HC}) 3$.

106 Rep v Mulolo Confirmation Case No 362 of 2012 (HC) 4

107 Rep $v$ Kanyumba Confirmation Case No 904 of 2008 (HC) 4.

108 Rep v Nkhata Confirmation Case No 534 of 2003 (HC), holding that punishment should not be used as a warning to the general public because this is punishing an offender for wrongs he has not committed.

109 Rep v Jali Confirmation Case No 228 of 2013 (HC) 3. Also see Rep v Alick Confirmation Case No 725 of 2000 (HC) (the preference for specific deterrence in cases of young and first offenders means that sentences in such cases "should fit the crime, the offender the victim and the public interest in preventing crime"); Rep $v$ Akishoni Confirmation Case No 196 of 1997 (HC) ("it should be really seldom that first offenders should receive sentences whose purpose is to prevent others from crime. Consequently, a first offender should only receive [a punishment that prevents] him from further mischief. This will be achieved if the sentence fits the crime, the offender, the plight of the victim and the public interest in preventing crime"). Also see Rep v Headson Confirmation Case No 129 of 2013 (HC) 4.
} 
imposed on first and young offenders should only aim at specific deterrence and that general deterrence may still be achieved as "a matter of course". ${ }^{110}$ It has been held that first and young offenders should not be used as "means to the end of", ${ }^{111}$ "as guinea pigs"112 or "scapegoats"113 for general deterrence and that

[s] uch sentences would be degrading cruel and [inhumane] punishment or treatment. ${ }^{114}$

It has been held that such offenders may be reformed or deterred from future crime by the likelihood or certainty of punishment rather than its severity. ${ }^{115}$ Therefore, it is considered that for first and young offenders, "a short, sharp and quick sentence may just be as effective as a longer one". 116 For repeat offenders, however, the use of sentences aimed at general deterrence is justified because society should be protected from repeat criminal conduct. ${ }^{117}$ In other words, longer sentences are more appropriate for repeat offenders as they have not been deterred by previous punishment and are unlikely to be deterred by the likelihood of punishment.

The reluctance of courts to employ general deterrence as a justification for the punishment of first and young offenders reflects the criticism advanced earlier against deterrence and utilitarianism in general, namely, the instrumentalisation of an offender. What is unique with the sentencing jurisprudence in Malawi is that courts regard general deterrence as an unsuitable goal for the punishment of first and young offenders. This qualified criticism of general deterrence raises questions in the light of the Bill of Rights. For instance, is it acceptable for a second custodial sentence to be disproportionate? Secondly, how justifiable is general deterrence for offenders other than first and young offenders?

It can be argued that courts are overly speculative when it comes to justifying leniency in sentencing first and young offenders. With respect, there seems to be no demonstrable basis for claims such as that lengthy sentences "backfire" by breeding vengeance which may promote

110 Rep v Banda Confirmation Case No 633 of 1999 (HC); Mtanga v Rep Criminal Appeal No 15 of 1998 (HC).

111 Rep v Alick Confirmation Case No 725 of 2000 (HC); Rep v Mwakikunga Confirmation Case No 326 of 1998 (HC).

112 Rep v Nkhoma Confirmation Case No 3 of $1996(\mathrm{HC})$.

113 Rep v Akishoni Confirmation Case No 196 of 1997 (HC). Also see Mwachilira v Rep Criminal Appeal Case No 86 of 2006 (HC) (there is something "unwholesome" about using first offenders as a means to an end).

114 Rep $v$ Samson Confirmation Case No 169 of 2013 (HC) 4-5.

$115 R e p v$ Sakhwinya Confirmation Case No 359 of 2013 (HC).

116 Rep v Sakhwinya Confirmation Case No 359 of 2013 (HC).

117 See Rep v Kufandiko Confirmation Case No 126 of 2009 (HC) 6. 
recidivism. In any event, there is no reason why the claim, if true, should not hold true for other offenders as well, unless, of course, they are locked away for such a long time that by the time they are released they are too old to commit certain crimes.

The qualified use of general deterrence is clearly rooted in the conceptualisation of general deterrence as synonymous with disproportionately lengthy sentences. Restricting general deterrence to repeat offenders is essentially an endorsement that they may be punished with disproportional sentences. This downplays the instrumentalisation of repeat offenders. The selective application of general deterrence is partly justified on the grounds of community protection. However, the need to protect society does not arise from the fact that the offender is not a first offender but rather from the extent to which the offence compromises public safety. Surely, a first-time murderer compromises public safety more than a repeat petty offender? An argument can be made that the way in which general deterrence is applied in Malawi is indefensible considering the rights to human dignity and equality. If general deterrence reduces an offender to a "guinea pig" then it should be a wholly objectionable goal of punishment regardless of the status of an offender. As held in Makwanyane, the instrumentalisation of an offender violates the right to human dignity. ${ }^{118}$ The age or criminal record of an offender is of no consequence. Otherwise, compliance with the non-discrimination injunction in section 20 of the Constitution may be called into question.

The discussion on deterrence reveals that the way general deterrence is applied in Malawi results in sentences that are inconsistent with the principle of proportionality and therefore violates the right to human dignity and the prohibition of cruel, inhumane and degrading punishment. Once the element of disproportionality in general deterrent sentences is removed, the justification for not imposing general deterrent sentences on first and young offenders becomes vague. The concern will then be whether the sentence is proportional to the offence and the offender. If, as has been suggested in various sentencing judgments, general deterrence can be achieved as "a matter of course", then there is no reason to actively pursue it by increasing sentences.

In view of the foregoing, there is no proper justification for not applying the same objections against general deterrence to repeat offenders. General deterrence should be an objectionable goal of punishment if it results in sentences that are cruel, inhuman or degrading by reducing an offender to

$118 S$ S Makwanyane 19953 SA 391 (CC) paras 313 and 316. 
a "guinea pig" or "a means to an end". It should not make any difference whether an offender is a first or repeat offender, young or old. The reason for this is that the right to human dignity is violated if offenders are reduced to a means to an end. Criticism from some judges that general deterrence is generally an inappropriate aim of punishment lends credence to the argument that the way general deterrence is understood and applied in Malawi results in sentences that are disproportionate and inconsistent with the right to human dignity and the prohibition of cruel, inhumane and degrading punishment.

The selective application of general deterrence also defies the deterrent effect of the certainty of punishment. As noted earlier, the certainty of punishment is a key concept in deterrence theory in general, and if there is no likelihood of actually being caught, prosecuted and punished, a person is likely to commit a crime. There is no compelling reason for applying the certainty principle to young offenders only.

\subsection{Deterrence and sentencing policy}

The High Court has held that whether or not a sentence in fact achieves deterrence should be the concern of penologists and not courts. ${ }^{119}$ It has also found that where certain levels of sentences are incapable of affecting crime, it is in the public interest that courts should shift their sentencing policy so that it reflects the public interest in curbing crime. ${ }^{120}$ According to Rep $v$ Adam, ${ }^{121}$

\footnotetext{
[w] hen that point is reached, individual personal circumstances have to be weighed against public interest. The way forward, a way justified by public policy, is to attach a premium on conventional sentences to reflect the need to deter crime by enhancing sentences.
}

Consequently, deterrence has been used as a justification for increasing the levels of sentencing where past sentences are perceived to have been unsuccessful in reducing crime. For example, Rep $v$ Bayani $i^{122}$ held that the prevalence of an offence means that the prevailing sentencing policy has failed to dissuade potential or repeat offenders because of inadequate punishment either as provided by statute or as passed by courts. The court held that in the latter scenario, the solution is for courts to generally increase the sentences imposed. Similarly, Rep $v$ Nyungwe, ${ }^{123}$ held that the

\footnotetext{
119 Rep v Adam Confirmation Case No 500 of 1995 (HC) 2.

$120 \quad$ Rep v Adam Confirmation Case No 500 of 1995 (HC) 2.

121 Rep v Adam Confirmation Case No 500 of 1995 (HC) 2.

122 Rep v Bayani Confirmation Case No 11 of 2000 (HC).

123 Rep v Nyungwe [1997] 2 MLR 127 (HC) 130.
} 
"phenomenal upsurge" in burglary cases at the time was partly because of "the sentencing policy of our courts", which passed "medium sentences" on offenders.

It was this perception that lengthier sentences could curb crime that prompted the issuance of the sentencing guideline two decades ago in Chizumila, one of the earliest reported cases after 1994, that has had a great impact on sentencing trends for burglary and housebreaking. The allegation in Chizumila is that short sentences are responsible for the increase in burglary cases and that mob justice is a result of public dissatisfaction with lenient sentences. ${ }^{124}$ Thus, the court suggested a departure from lenient sentences in cases of burglary and housebreaking, recommending that the starting point for burglary should be six years. ${ }^{125} \mathrm{At}$ the time, this was about six times and twice the average sentence previously imposed on first and repeat offenders respectively. ${ }^{126}$ Similar reasoning is evident in Mulewa $v R_{e} p^{127}$ where the court, despite noting that long sentences have not necessarily led to a decrease in crime and uncertainty as to whether the length of sentences was responsible for the increase in crime, imposed a higher sentence to curb crime and the incidence of mob justice. This tendency has been justified on the basis that courts should be responsive to public outcry. ${ }^{128}$ In other words, the lengthier sentences are meant to satisfy public sentiment.

It is noteworthy that some cases have not supported the general principle that serious offences should be punished with long and immediate imprisonment. For example, it was said in Rep $v$ Limbani that in view of prison conditions, courts should follow "a deliberate policy of decongesting prisons" by imposing short sentences even for serious offences such as manslaughter, robbery, rape, defilement, burglary, housebreaking, the theft of a bicycle, the theft of livestock "and many more ... in the category of serious offences". 129

The High Court has pointed out that guidelines that emphasise long periods of imprisonment for serious offences are skewed because they ignore the importance of the reformation of the offender and focus only on retributive

\footnotetext{
124 Chizumila 306.

125 Chizumila 306.

126 Chizumila 306: "Up to about three months ago [September 1994], sentences passed by the courts have generally been short-term sentences ranging between 9-30 months for burglary. Longer sentences of up to 36 months have been reserved for repeat offenders".

127 Mulewa v Rep [1997] 2 MLR $60(\mathrm{HC})$.

128 Rep v Makata Confirmation Case 968 of $1996(\mathrm{HC})$.

129 Rep v Limbani Confirmation Case No 839 of 2005 (HC) 2.
} 
justice and deterrence without any consideration of the negative consequences of long sentences both on an offender and on others. ${ }^{130}$ Contending that short sentences can be as effective as long sentences and that the criminals are deterred more by getting caught and punished, Ndovi $\mathrm{J}$ observed in Rep $v$ Kholoviko: ${ }^{131}$

The courts must also consider how such long sentences that are advocated can deter other accused persons, present as well as future ones. There is no evidence that these offences have reduced by reason of long sentences. In fact, they are on the increase. For first time offenders, not only common sense but the law as well, require[s] that they should not be sent to prison willy-nilly. They should only be sent to prison if there are real and compelling reasons for doing so. This court does not believe, nor is it convinced, that mere trend or level or even conventional sentences alone have any impact on the accused himself. It may have merit on generating confidence in the courts and promoting the concept of predictability of the sentences that the courts will impose generally, but there is no real impact on deterrence and reformation.

The court added that effectiveness in law enforcement as seen for instance through arrests, convictions and the recovery of stolen property, which may deter a person from embarking on a criminal career by creating

... a lingering possibility of being caught and deprived of the fruits of his or her nefarious activity. ${ }^{132}$

These views have not found much common ground. In fact, post-1994 sentencing practices indicate a gradual increase in the severity of sentences. For instance, in some cases the recommended starting points for serious offences have tripled. ${ }^{133}$ Furthermore, although the justification for leniency in dealing with first and young offenders has remained largely the same after 1994, the duration of the sentences imposed on them has increased. Courts have advocated stiffer sentences in view of public opinion and the prevalence of serious offences. ${ }^{134}$ The Sentencing guidelines now provide for starting points that are much higher than the sentences imposed before 1994. For instance, sentences for burglary used to range from 9-30 months for first offenders and three years for repeat offenders. The starting

130 Rep v Kholoviko [1996] MLR 355 (HC) (hereafter Kholoviko).

131 Kholoviko 359-360. Also see Rep v Mwakikunga Confirmation Case No 326 of 1998 (HC) (public deterred by a "real possibility that a first offence could land you in jail"); Rep v Magombo Confirmation Case No 264 of 2011 (HC) ("the likelihood and possibility of prison sentence may be more effective than actual imprisonment").

132 Kholoviko 360.

133 For instance, in 1987, Rep $v$ Msowoya [1987-1989] 12 ALR Mal 394 (HC) recommended that a sentence for rape should start at three years, while in 2007 the Judiciary recommended a starting point of 10 years: see Malawi Judiciary Magistrate's Court Sentencing Guidelines 5. However, Nani v Rep Criminal Appeal No 1 of 2011 (HC) recommended a starting point of six years. Chizumila 306; Rep v Wilson; Rep v Khapuleni [1995] 2 MLR 567 (HC) 571. 
point for a threshold case of burglary is now six years. These developments are premised mainly on the pursuit of deterrence, because it is believed that stiffer sentences have a greater deterrent value. This understanding is also responsible for the recent enhancement of maximum sentences in the Penal Code. In the long run, these enhancements will lead to lengthier sentences since the maximum sentence is an indicator of the seriousness of an offence, which is the most determinative factor on the quantum of punishment. ${ }^{135}$

The continued justification of long sentences on the basis of general deterrence is particularly perturbing in the light of seeming judicial indifference to whether or not longer sentences in fact have a greater deterrent value than shorter sentences. Case law does not indicate why lengthier sentences are considered to have a greater deterrent effect. Courts readily assume that punishment has a deterrent effect and that heavier sentences have a greater deterrent value than lighter sentences. This is not necessarily the case and is symptomatic of the pitfalls of deterrence.

Therefore, Chizumila can be criticised for concluding, without much proof, that short sentences were the reason for the increase in burglary cases at the time. Mob justice cannot be blamed on sentencing alone and it is not entirely correct to claim that mob justice is an indicator of society's views as to the appropriate punishment. In the face of high crime rates, mob justice in Malawi is most probably fuelled by a general dissatisfaction with the criminal justice system including the failure of police to apprehend suspects and the release of suspects on bail. This dissatisfaction is in fact antagonistic to the presumption of innocence, especially where an offender was caught in flagrante delicto. It is ironic that while courts are unsure as to the underlying reasons for an upsurge in mob justice incidents, they have by and large responded by imposing harsher sentences. Courts cannot endorse such societal views, which at best are uninformed of the sentencing process and the circumstances that inform it. Indeed, the question of whether or not the sentences imposed on offenders are adequate cannot be determined through the lenses of perpetrators of mob justice. The majority of such people cannot be within the remit of - to use the words of Chombo J - "right-thinking members of the public with full knowledge of the relevant facts and circumstances" of the case and who upon learning of the sentence can "question the court's sanity" or wonder if "something had gone

135 Patel v S Criminal Appeal No 81 of $2007(\mathrm{HC})$; Rep v lddi Confirmation Case No 48 of $1998(\mathrm{HC})$. 
wrong with the administration of justice". ${ }^{136}$ After all, it is questionable whether judicial officers in fact know the views of society. ${ }^{137}$

A crucial question that Chizumila raises is how a court can, on the one hand, be ostensibly unconcerned about whether imprisonment succeeds in deterring offenders and, on the other, justify increasing the level of sentences on the basis that lower sentences are incapable of reducing crime. The latter reasoning can hold only if the deterrent effect of imprisonment is certain and it is known that longer sentences have a greater deterrent effect. Therefore, if the court is not interested in knowing whether deterrence is at all achieved by imprisonment then it has no basis for adopting a sentencing policy that imposes longer sentences in a bid to attain deterrence. Such sentences would be contrary to the right to liberty in that the deprivation of liberty is not rationally connected to its stated aim. It is paradoxical that a court, as the authority responsible for depriving an offender of' liberty, has no interest in knowing if the stated aim can be achieved but rather proceeds on an assumption that the deprivation of liberty for a longer time will achieve the desired goal. A limitation of a right is justifiable in terms of section 44 of the Constitution if, among other things, it is reasonable in that the aim it seeks to achieve is actually achieved. In the context of imprisonment, the deprivation of liberty cannot pass constitutional scrutiny where the authority restricting the right is indifferent to whether such deprivation will in fact achieve the stated objective.

Furthermore, the tendency to enhance sentences with little concern as to whether the purpose for the enhancement will be achieved violates the right to human dignity, because it reduces an offender to a means to an end. In this case, an offender is used purely to satisfy public sentiment without any regard as to whether the restriction of his rights will achieve the legitimate goal of reducing crime. Sentencing cannot be led by public sentiment alone; ${ }^{138}$ if anything, courts must lead public opinion by upholding the constitutional rights of offenders. In addition, it is not proper for a court to be indifferent to whether an enhanced sentence has a greater deterrent value than a lesser sentence, since a limitation must constitute the least restrictive means to achieve the objective. Needless to say, public sentiment is not a lawful basis on which the right to liberty may be limited. In the case of imprisonment, a court cannot justifiably impose a longer sentence in the absence of proof that a shorter sentence (a less restrictive means) cannot achieve the same objective. This is supported by Chikopa $\mathrm{J}$ in $\operatorname{Rep} v$

\footnotetext{
136 Rep v Masula Criminal Case No 65 of 2008 (HC) 4.

137 Terblanche Guide to Sentencing 166.

138 S v Makwanyane 19953 SA 391 (CC) paras 87-89, 187, 199, 265 and 304.
} 
Kapitawo, where it was held that a court must not only state its basis for claiming that an offence is prevalent but also why the offence is on the increase and how or why a stiffer sentence would reverse the situation. ${ }^{139}$ Such statements, the judge continued, are matters of fact, the truth of which must be carefully established beyond reasonable doubt. ${ }^{140}$ Therefore, indifference to the realisation of the aims of punishment is indefensible and duplicitous.

\subsection{Going beyond deterrence}

It is important to note some recent developments regarding the role of deterrence in sentencing. In 2013 the High Court issued a string of judgments advocating a shift in sentencing policy regarding the punishment of serious offences. ${ }^{141}$ It urged courts to move beyond deterrence as the goal of punishment and consider rehabilitation as a legitimate purpose of punishment. For instance, in Rep $v$ Keke it was held that public interest goes beyond deterrence and extends to the reformation of an offender so that the punishment process results in making him a better person in the community. ${ }^{142}$ Further, in a clear departure from the principles advanced in earlier cases like Chizumila, the High Court has held that immediate imprisonment should not be seen as an automatic disposal of serious offences such as burglary and housebreaking; such offences may be punished with suspended sentences or indeed a non-custodial sentence altogether. ${ }^{143}$ It has also encouraged the use of non-custodial sentences for simple theft. ${ }^{144}$

\footnotetext{
139 Rep v Kapitawo Confirmation Case No 303 of 2005 (HC) 3

140 Rep v Kapitawo Confirmation Case No 303 of 2005 (HC) 3.

141 See, for instance, Rep v Mushali Confirmation Case No 242 of 2013 (HC) 3; Rep v Assam Confirmation Case No 907 of 2008 (HC) 3; Rep v Chirwa Confirmation Case No 271 of 2013 (HC) 3; Rep v Kanyumba Confirmation Case No 904 of 2008 (HC) 3; Rep v Mulolo Confirmation Case No 362 of 2012 (HC) 3; Rep v Kandodo Confirmation Case No 240 of 2013 (HC) 3; Rep v Kanena Confirmation Case No 130 of 2013 (HC) 3; Rep v Headson Confirmation Case No 129 of 2013 (HC) 3; Rep $v$ Jali Confirmation Case No 228 of 2013 (HC) 3; Rep v James Confirmation Case No 244 of 2013 (HC) 3; Rep v John Confirmation Case No 528 of 2010 (HC) 4; Rep v Mapeni Confirmation Case No 466 of 2010, 3; Rep v Kaufa Confirmation Case No 314 of 2011 (HC) 3; Rep v Naphazi Confirmation Case No 386 of 2011 (HC) 3. All the judgments were authored by Mwaungulu $\mathrm{J}$, as he then was.

142 Rep v Keke Confirmation Case No 404 of 2010 (HC) 8

143 Rep v James Confirmation Case No 244 of 2013 (HC) 3. Also see Rep v Mushali Confirmation Case No 242 of 2013 (HC) 3; Rep v Chirwa Confirmation Case No 271 of 2013 (HC) 3; Rep v Kandodo Confirmation Case No 240 of 2013 (HC) 3; Rep v Mapeni Confirmation Case No 466 of 2010 (HC) 3; Rep v Yasin Confirmation Case No 219 of 2012 (HC) 3.

$144 R e p$ v Kotamu Confirmation Case No 180 of 2012 (HC) 6.
} 


\section{Conclusion}

While Malawian courts have long invoked deterrence in sentencing offenders, they have not delved into the philosophical aspects of this theory. Deterrence retains a significant role in sentencing and is often cited to justify stiff sentences for serious and prevalent offences. Malawian sentencing jurisprudence reflects some of the shortcomings of deterrence. While courts recognise that deterrence carries the risk of the instrumentalisation of offenders, this is deemed problematic only when dealing with first offenders. Further, general deterrence is understood to require punishment that exceeds what is proportional to the offence. It is therefore recommended that courts should give rehabilitation a greater role in sentencing and infuse sentencing decisions with constitutional and international standards. Courts should also reconsider the conceptualisation of general deterrence. Indeed, once it is accepted, as Malawian courts have done, that general deterrence may lead to disproportionate sentences, and that this would infringe the right to human dignity and the prohibition of cruel and degrading treatment, it is futile to assert that repeat offenders may be subjected to general deterrent sentences. It must be recalled that the right to human dignity will be violated where the length of sentence is not commensurate with the gravity of an offence, regardless of whether the sentence has been overtaken by penal objectives such as deterrence or even rehabilitation. In this regard, it is recommended that courts must adopt a stricter interpretation of proportionality, which does not allow for punishment that exceeds the bounds commensurate with the offence.

\section{Bibliography}

\section{Literature}

Andenaes Punishment and Deterrence

Andenaes J Punishment and Deterrence (Michigan University Press Ann Arbour 1974)

Apel and Nagin "General Deterrence"

Apel R and Nagin DS "General Deterrence: A Review of Recent Evidence" in Wilson JQ and Petersilia J (eds) Crime and Public Policy (Oxford University Press New York 2011) 411-436

Bentham "Comment on the Commentaries"

Bentham $J$ "A Comment on the Commentaries and a Fragment on Government" (edited by Burns JH and Hart HLA) in The Collected Works of Jeremy Bentham (Oxford University Press London 1977) 
Bentham Principles of Morals and Legislation

Bentham J An Introduction to the Principles of Morals and Legislation (edited by Burns JH and Hart HLA) (Methuen London 1982)

Bykvist Utilitarianism

Bykvist K Utilitarianism: A Guide for the Perplexed (Continuum International London 2010)

Cavadino and Dignan Penal System

Cavadino M and Dignan J The Penal System: An Introduction (SAGE London 2002)

Chirwa Human Rights under the Malawian Constitution

Chirwa DM Human Rights under the Malawian Constitution (Juta Cape Town 2011)

Christopher 2002 NWULR

Christopher RL "Deterring Retributivism: The Injustice of 'Just' Punishment" 2002 Northwestern University Law Review 843-976

Fox and Freiberg Sentencing

Fox R and Freiberg A Sentencing: State and Federal Law in Victoria (Oxford University Press Oxford 2001)

Geerken and Gove 1975 Law \& Soc'y Rev

Geerken MR and Gove WR "Deterrence: Some Theoretical Considerations" 1975 Law \& Soc'y Rev 497-513

Gumboh 2017 JAL

Gumboh E "A Critical Analysis of Life Imprisonment in Malawi" 2017 JAL 443-466

Hospers Human Conduct

Hospers J Human Conduct: An Introduction to the Problems of Ethics (Thomson Learning New York 1961)

Kant "Penal Law and the Law of Pardon"

Kant I "The Penal Law and the Law of Pardon" in Tonry M (ed) Why Punish? How Much? A Reader on Punishment (Oxford University Press Oxford 2010) 31-36

Maestro Cesare Beccaria

Maestro MT Cesare Beccaria and the Origins of Penal Reform (Temple University Press Philadelphia 1973) 
Malawi Judiciary Magistrate's Court Sentencing Guidelines

Malawi Judiciary Magistrate's Court Sentencing Guidelines (unpublished 2007)

Marsh, Cochrane and Melville Criminal Justice

Marsh I, Cochrane J and Melville G Criminal Justice: An Introduction to Philosophies, Theories and Practice (Routledge London 2004)

Terblanche Guide to Sentencing

Terblanche SS Guide to Sentencing in South Africa (LexisNexis Durban 2009)

Van Den Haag 1982 J Crim L \& Criminology

Van Den Haag E "Could Successful Rehabilitation Reduce the Crime Rate?" 1982 J Crim L \& Criminology 1022-1035

Wasik Emmins on Sentencing

Wasik J Emmins on Sentencing (Blackstone London 1998)

Zimring Perspectives on Deterrence

Zimring FE Perspectives on Deterrence (National Institute of Mental Health Washington 1971)

\section{Case law}

Banda v Rep [1990] 13 MLR 56 (SCA)

Banda v Rep Criminal Appeal No 221 of 2009 (HC)

Bwanali v R [1964-1966] 3 ALR Mal 329 (HC)

Chief Public Prosecutor v Nkosi [1990] 13 MLR 97 (HC)

Chitsonga $v$ Rep [1995] 1 MLR 86 (HC)

Dandaula v Rep Criminal Appeal No 11 of 2008 (HC)

Daukire v Rep Criminal Appeal No 148 of 2004 (HC)

John v Rep Criminal Appeal No 131 of 1975 (HC)

Kafkaris v Cyprus [2008] ECtHR

Kalambo v Rep Criminal Appeal No 199 of 1975 (HC) 
Kamil v Rep [1973-1974] 7 MLR 169 (SCA)

Kanyinji v Rep Criminal Appeal No 116 of 2008 (HC)

Kapolo v Rep Criminal Appeal No 82 of 2007 (HC)

Kumwenda v Rep (1993) 16(1) MLR 233 (SCA)

Lobo v Rep Criminal Appeal No 110 of 2008 (HC)

Lusale v Rep Criminal Case No 141 of 2005 (HC)

Maikolo v R [1964-1966] 3 ALR Mal 584 (SCA)

Makanjira v Rep Criminal Appeal No 67 of 2007 (HC)

Makawa $v$ Rep Criminal Appeal No 196 of 1975 (HC)

Maniote v Rep [1984-1986] 11 ALR Mal 174 (HC)

Masangano v Attorney General Constitutional Case No 15 of 2007 (HC)

Mbekeani v Rep Criminal Appeal No 48 of 2006 (HC)

Millo v Rep Criminal Appeal No 30 of $2000(\mathrm{HC})$

Moses v Rep Confirmation Case No 140 of 2011 (HC)

Mpondamwala v Rep [1984-1986] 11 ALR Mal 306 (HC)

Mtanga $v$ Rep Criminal Appeal No 15 of 1998 (HC)

Mtetera v Rep Criminal Appeal No 88 of 2005 (HC)

Mulewa v Rep [1997] 2 MLR 60 (HC)

Mussa v Rep Criminal Appeal No 44 of 1995 (HC)

Mwachilira v Rep Criminal Appeal Case No 86 of 2006 (HC)

Nani v Rep Criminal Appeal No 1 of 2011 (HC)

Patel v S Criminal Appeal No 81 of $2007(\mathrm{HC})$

$R$ v Curran 57 Cr App R 945

$R v$ Robert [1961-1963] 2 ALR Mal 291 (HC) 
$R v$ White [1923-1960] 1 ALR Mal $401(\mathrm{HC})$

$R v$ Zagwa [1923-1960] 1 ALR Mal $415(\mathrm{HC})$

Rendall-Day v Rep[1966-1968] 4 ALR Mal 155 (HC)

Rep v Adam Confirmation Case No 500 of 1995 (HC)

Rep v Akishoni Confirmation Case No 196 of 1997 (HC)

Rep v Alick Confirmation Case No 725 of 2000 (HC)

Rep v Asidi Confirmation Case No 955 of 1999 (HC)

Rep v Assam Confirmation Case No 907 of 2008 (HC)

Rep v Austin Confirmation Case No 1222 of 2003 (HC)

Rep v Banda [1984-1986] 11 ALR Mal (HC)

Rep v Banda Confirmation Case No 633 of 1999 (HC)

Rep v Bayani Confirmation Case No 11 of 2000 (HC)

Rep v Chavula Criminal Appeal No 93 of 2005 (HC)

Rep v Chikwana Confirmation Case No 131 of 2013 (HC)

Rep v Chilenje [1996] MLR 361 (HC)

Rep v Chimbelenga [1996] MLR 342 (HC)

Rep v Chinthiti (2) [1997] 1 MLR 70 (HC)

Rep v Chirwa Confirmation Case No 271 of 2013 (HC)

Rep v Chitseko Confirmation Case No 78 of 1997 (HC)

Rep v Chizenga Confirmation Case No 297 of 2008 (HC)

Rep v Chizumila [1994] MLR $288(\mathrm{HC})$

Rep v Domingo Confirmation Case No 850 of 1990 (HC)

Rep v Eneya Criminal Case No 53 of 2003 (HC)

Rep v Foster Confirmation Case No 1690 of 2005 (HC) 
Rep v Gwaza [1995] 2 MLR 752 (HC)

Rep v Harry [1997] 1 MLR $119(\mathrm{HC})$

Rep v Harry [1997] 2 MLR $74(\mathrm{HC})$

Rep v Havula [1991] 14 MLR 429 (HC)

Rep v Headson Confirmation Case No 129 of 2013 (HC)

Rep v Iddi Confirmation Case No 48 of 1998 (HC)

Rep v Jali Confirmation Case No 228 of 2013 (HC)

Rep v James Confirmation Case No 244 of 2013 (HC)

Rep v Jeke Confirmation Case No 178B of 2013 (HC)

Rep v John Confirmation Case No 528 of 2010 (HC)

Rep v Josephy Confirmation Case No 261 of 2013 (HC)

Rep v Jumbe Criminal Appeal No 565 of 2008 (HC)

Rep v Kachimanga Confirmation Case No 1746 of 2007 (HC)

Rep v Kafwambira Confirmation Case No 37 of 2008 (HC)

Rep v Kandodo Confirmation Case No 240 of 2013 (HC)

Rep v Kanena Confirmation Case No 130 of 2013 (HC)

Rep v Kanyumba Confirmation Case No 904 of 2008 (HC)

Rep v Kapitawo Confirmation Case No 303 of 2005 (HC)

Rep v Kathumba [1997] 1 MLR $390(\mathrm{HC})$

Rep v Katole [1993] 16(1) MLR 472 (HC)

Rep v Kaufa Confirmation Case No 314 of 2011 (HC)

Rep v Kayenda Confirmation Case No 220 of 2003 (HC)

Rep v Keke Confirmation Case No 404 of 2010 (HC)

Rep v Kholoviko [1996] MLR 355 (HC) 
Rep v Kotamu Confirmation Case No 180 of 2012 (HC)

Rep v Kufandiko Confirmation Case No 126 of 2009 (HC)

Rep v Lampu Confirmation Case No 89 of 1996 (HC)

Rep v Limbani Confirmation Case No 839 of 2005 (HC)

Rep v Madando [1995] 2 MLR 733 (HC)

Rep v Madelube Criminal Case No 105 of 2008 (HC)

Rep v Mafaiti Confirmation Case No 660 of 1990 (HC)

Rep v Magombo Confirmation Case No 264 of 2011 (HC)

Rep v Makata Confirmation Case 968 of 1996 (HC)

Rep v Mapeni Confirmation Case No 466 of 2010 (HC)

Rep v Masula Criminal Case No 65 of 2008 (HC)

Rep v Matiki [1997] 1 MLR 159 (HC)

Rep v Matindi Confirmation Case No 1699 of 1976 (HC)

Rep v Misomali Confirmation Case No 527 of 1996 (HC)

Rep v Mkoma [1995] 2 MLR 598 (HC)

Rep v Mpira [1982-1984] 10 ALR Mal 67 (HC)

Rep v Msowoya [1987-1989] 12 ALR Mal 394 (HC)

Rep v Mtaya Confirmation Case No 98 of 1995 (HC)

Rep v Mulolo Confirmation Case No 362 of 2012 (HC)

Rep v Mushali Confirmation Case No 242 of 2013 (HC)

Rep v Mutawo Confirmation Case No 237 of 1999 (HC)

Rep v Mwakikunga Confirmation Case No 326 of 1998 (HC)

Rep v Mzuzi Confirmation Case No 1607 of 1998 (HC)

Rep v Nabanda [1984-1986] 11 ALR Mal 166 (HC) 
Rep v Naphazi Confirmation Case No 386 of 2011 (HC)

Rep v Napulula Confirmation Case No 665 of 2003 (HC)

Rep v Ndamera Confirmation Case No 314 of 2001 (HC)

Rep v Ngomwa Confirmation Case No 1021 of 2003 (HC)

Rep v Nkhata Confirmation Case No 534 of 2003 (HC)

Rep v Nkhoma Confirmation Case No 3 of 1996 (HC)

Rep v Nthara [1984-1986] 11 ALR Mal 338 (HC)

Rep v Nyungwe [1997] 2 MLR 127 (HC)

Rep v Phale [1991] 14 MLR 438 (HC)

Rep v Phiri [1984-1986] 11 ALR Mal 176 (HC)

Rep v Phiri [1993] 16(2) MLR 748 (HC)

Rep v Phiri [1996] MLR 365 (HC)

Rep v Phiri [1997] 2 MLR 92 (HC)

Rep v Sakhwinya Confirmation Case No 359 of 2013 (HC)

Rep v Samson Confirmation Case No 169 of $2013(\mathrm{HC})$

Rep v Sozinyo [1997] 2 MLR 16 (HC)

Rep v Tembo Confirmation Case No 726 of 2000 (HC)

Rep v Tembo Confirmation Case No 187 of 2013 (HC)

Rep v Tomasi [1997] 2 MLR 70 (HC)

Rep v Wilson; Rep v Khapuleni [1995] 2 MLR 567 (HC)

Rep v Yasin Confirmation Case No 219 of 2012 (HC)

S v Makwanyane 19953 SA 391 (CC)

Vinter $v$ United Kingdom Application Nos 66069/09, 3896/10 and 130/10, Merits, 9 July 2013 (ECtHR) 
White $v$ Rep Criminal Appeal No 19 of 2007 (HC)

\section{Legislation}

Constitution of the Republic of Malawi, 1994

Penal Code, Chapter 7:01 of the Laws of Malawi

Road Traffic Act, Chapter 69:01 of the Laws of Malawi

International instruments

International Covenant on Civil and Political Rights (1966)

\section{Internet sources}

Beccaria 1764 http://files.libertyfund.org/files/2193/Beccaria_1476_EBk_v 6.0.pdf

Beccaria CB 1764 An Essay on Crimes and Punishments http://files.libertyfund.org/files/2193/Beccaria_1476_EBk_v6.0.pdf accessed 20 November 2017

\section{List of Abbreviations}

$\begin{array}{ll}\text { J Crim L \& Criminology } & \text { Journal of Criminal Law and Criminology } \\ \text { JAL } & \text { Journal of African Law } \\ \text { Law \& Soc'y Rev } & \text { Law and Society Review } \\ \text { MSCA } & \text { Malawi Supreme Court of Appeal } \\ \text { NWULR } & \text { Northwestern University Law Review }\end{array}$

